\title{
The Nauplii of Notodelphys agilis Thorell and Doropygus porcicauda Brady.
}

\author{
By \\ Peter Gray, Ph.D., A.R.C.s., \\ Lecturer in Vertebrate Embryology in the Department of Zoology of the \\ University of Edinburgh.
}

With 1 Figure in the Text.

\section{INTRODUCTION.}

THE Notodelphoidea are a heterogeneous collection of copepods which are found parasitic within urochordates and there is considerable doubt as to the exact systematic position which should be occupied by this group. It comprises - in the sense in which it is used by Sars (1921) — six families of excessively doubtful affinities in that there are grouped together Copepods (1) which brood their eggs (Notodelphys, Doropygus, etc.), (2) others which are possessed of elongate egg-strings (Entericola), (3) and others which deposit their eggs singly (Mycophilus). Now it appears to the present writer that such great variation in habit must argue an equally great variation in the structure of the genital organs, for the "cement gland" and "hardening gland" (see Gray, 1928) may be presumed to be absent if egg-strings are not formed. It is doubtful, therefore, whether any useful discussion on the classification of these forms can take place without a parallel and detailed investigation of the internal anatomy. There is, however, another line of approach-the study of larval forms. It is equally as a preliminary skirmish along this line of attack, and as a contribution to our knowledge of larval forms, that the present brief note is presented.

\section{Material.}

Doropygus porcicauda occurs with moderate frequency within the branchial basket of Corella parallelograma at Millport. The eggs contained within the brood pouch are an exceedingly dark olive-green, a colour which is retained by the nauplius. All the eggs in any pouch appear to be at the same stage of development and hatch into a first nauplius before birth. These nauplii are then forced out by an arching of the back of the parasite, and appear incapable of movement for about ten seconds, after which 
they swim with the usual jerky motion. Only a single specimen gave birth to nauplii while under observation.

Notodelphys agilis is much rarer and was taken only twice, in each instance from the branchial basket of Ascidicola virginea. In one case the nauplii had been shed only a few seconds before the host was opened up, but there were a few specimens remaining in the brood pouch and these were dissected out.

The attempt to rear these nauplii was unsuccessful.

\section{DESCRIPTION.}

Nauplius of Notodelphys agilis Thorell (Fig. 1A).

Body in shape a cylinder with rounded ends, dark olive-green, greatly distended with yolk globules. The labrum is exceedingly small; at the posterior end of the body there are the usual small furcal setæ.
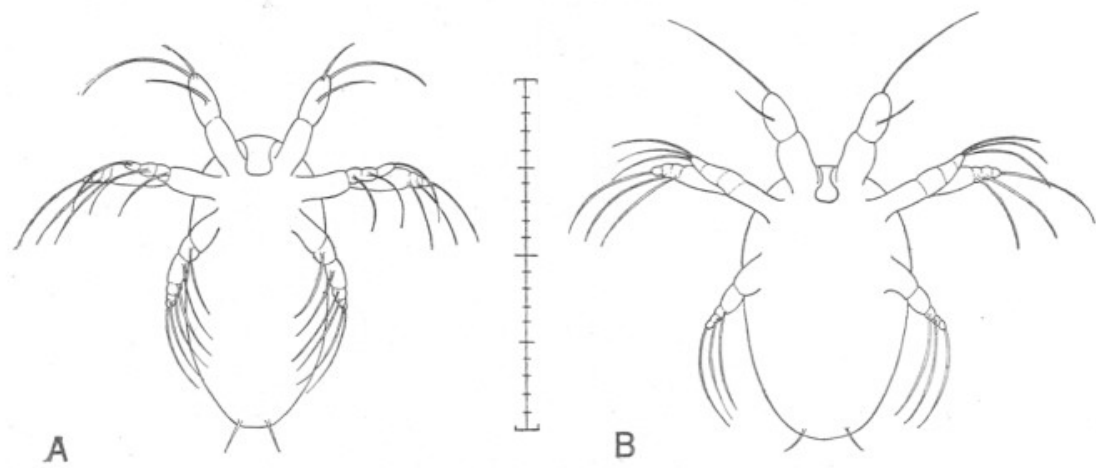

Fig. 1.-A. Nauplius of Notodelphys agilis Thorell. Ventral aspect.

B. Nauplius of Doropygus porcicauda Brady. Ventral aspect. (The scale represents $0.2 \mathrm{~mm}$. divided into 20 parts.)

Antenna I of two segments, the distal bearing one terminal and two ventral setæ, one of these latter being sub-terminal, the other arising just posterior to the middle of the segment.

Antenna II without demarcation between coxal and basal segments. Exopodite four-jointed, the proximal segment rather more than twice as long as the three terminals combined; each of the three terminals bears one long, recurved seta. Endopodite greatly reduced, of three segments, each bearing a recurved seta.

Mandible lacking the endopodite. This uniramous appendage shows six segments of which the terminal five bear long recurved setæ. 


\section{Nauplius of Doropygus porcicauda Brady (Fig. 1B).}

Body egg-shaped, of a dark olive-green and greatly distended with yolk. The labrum is even smaller than in the last; the furcal setæ are widely spaced and curve outwards.

Antenna I of two segments, the distal bearing an elongate recurved terminal seta and one short medially inserted seta.

Antenna II without demarcation between coxal and basal segments. Expodite of four segments, the proximal not greatly exceeding the length of the three distals combined; each distal bears a long recurved seta. Endopodite of three segments well developed, only the last bearing three terminal setæ.

Mandible lacking the endopodite. The appendage shows five segments of which only the three distal bear each a long recurved seta.

\section{Discussion.}

Both these nauplii differ sharply from all other known nauplii in the uniramous form of the mandible. The appendages are also rather more slender than is usual in the copepoda and bear considerably fewer setæ; indeed, the whole armature is greatly reduced, being obviously adapted for life under the highly specialised conditions into which the larvæ are born. The complete absence of spines from the bases of the first two appendages, coupled with the very great reduction of the labrum, render impossible the usual naupliar feeding mechanism and it seems obvious that the nauplius must depend upon its yolk reserves until a later instar.

The great reduction of the mandible is of the highest interest. The adult copepod is in both instances furnished in the adult with normal mandibles which are, however, absent from some other members of the group (e.g. Mycophilus). Yet the nauplius of this latter (Gray, 1932) is furnished with biramous mandibles! The great resemblance between the two forms shows clearly - what is in any case apparent from the adultthat the families Notodelphidæ and Doropygidæ are closely allied to each other.

The affinities of these families are rather interesting as there is, to my mind, little doubt that they are descended from a Calanoid ancestor. There is little or no resemblance, either as to habits, structure or lifehistory, with any Harpacticoid or Cyclopoid type. The resemblances with the Calanoid are both many and striking. The eggs of Calanus, for example, though not actually brooded, are at least accumulated in a dorsal chamber for a considerable time before laying; the eggs are, moreover, frequently of a dark olive-green colour, never observed in other groups of copepoda. The general shape of the nauplius and the actual armature 
of the appendages are similar in both groups and there are considerable resemblances between the adult appendages.

The writer is indebted to Mr. Richard Elmhirst, Superintendent of the Millport Marine Biological Station, for rendering possible the collection of the present material and for very considerable assistance in the identification of the hosts. The author also wishes to express his thanks to Professor J. H. Ashworth, F.R.S., for his criticism of the manuscript.

\section{LITERATURE CITED.}

Gray, Peter. 1928. The Internal Anatomy of Lerncoopoda scyllicola. Part I. Female. Quart. Journ. Micros. Sci., 72, p. 784.

Gray, Peter. 1933. Mycophilus rosovula n. sp., a Notodelphoid Copepod parasitic within B. (Botrylloides) leachii Sav., with a descriptîn of the Nauplius and Notes on the Habits. Journ. Mar. Biol. Assoc., N.S., Vol. XVIII, No. 2, p. 523.

SARS, G. O. 1921. An account of the Crustacea of Norway, Vol. 8, Bergen. 